\title{
The Correlation between Financial Literacy and Family Wealth Distribution in Bandung, Indonesia
}

\author{
R A Rahadi, J Danella, and L. Okdinawati
}

\begin{abstract}
Indonesia was considerably hit by the Asian financial crisis in 1997. Fortunately, since the crisis, Indonesia GDP steadily increased from $\$ 857$ in 2000 to $\$ 3,603$ in 2016 (World Bank, 2017). However, around $10 \%$ of the entire populations still live below the poverty line in 2016. Based on the results of the OJK survey, financial literacy level of Indonesia was $29.66 \%$ in 2016 . It increased by $7.82 \%$ from 2013 alongside with reduction of poverty rate of Indonesia, which decreased from $11.47 \%$ in 2013 to $10.70 \%$ in 2016 . Therefore, is there any relationship between financial literacy and poverty rate or wealth accumulation? From the result of a pilot testing, we hope to find the significant relationship between financial literacy and wealth of families in Bandung.
\end{abstract}

Index Terms - Financial literacy, wealth accumulation, household, financial education.

\section{INTRODUCTION}

Global financial crisis cannot easily affect the national economy if the people within the country have proper knowledge about the financial system [1]. Unfortunately, things were not always happened as expected as the statement above. When the financial crisis in Asia happened in 1997, several countries were burdened with significant foreign debt. Indonesia got the hardest hit because it affected the country not only economically, but also politically and socially. Rupiah was depreciated significantly, interest rate rose, and the country faced hyperinflation around 65\% in 1998 [2]. Indonesia became the country with an unfriendly atmosphere for investors and loaners. The poverty rate also kept increasing to $24.20 \%$ in 1998 from $11.30 \%$ in 1996 (Table 1). It was the first occurrence of an increasing poverty rate in Indonesia since 1976 [3].

Fortunately, since the Asian financial crisis in the late 1990s, Indonesia has demonstrated substantial economic growth that shown in steadily increased GDP from $\$ 857$ in 2000 to $\$ 3,603$ in 2016 [4].
Published on May 20, 2019

R. A. Rahadi is with the School of Business and Management, Institut Teknologi Bandung, Jl. Ganesha No. 10, 40132, Bandung, West Java, Indonesia (e-mail: aswin.rahadi@ @sbm-itb.ac.id).

J. Danella is with the School of Business and Management, Institut Teknologi Bandung, Jl. Ganesha No. 10, 40132, Bandung, West Java, Indonesia (e-mail: jasmine.danella@ sbm-itb.ac.id).

L. Okdinawati is with the School of Business and Management, Institut Teknologi Bandung, Jl. Ganesha No. 10, 40132, Bandung, West Java, Indonesia (e-mail: aneu.okdinawati@ @sbm-itb.ac.id).

\begin{tabular}{|c|c|c|c|}
\hline & 1996 & 1997 & 1998 \\
\hline GDP Growth & $8 \%$ & $4.7 \%$ & $(13.6 \%)$ \\
\hline Inflation Growth & $6.5 \%$ & $11.6 \%$ & $65 \%$ \\
\hline
\end{tabular}

TABLE 2 POVERTY RATE OF INDONESIA

\begin{tabular}{|c|c|c|c|}
\hline \multirow{2}{*}{ Year } & \multicolumn{3}{|c|}{ Poverty Rate (\%) } \\
\hline & Urban & Rural & Total \\
\hline 1976 & 38.80 & 40.40 & 40.10 \\
\hline 1978 & 30.80 & 33.40 & 33.30 \\
\hline 1980 & 29.00 & 28.40 & 28.60 \\
\hline 1981 & 28.10 & 26.50 & 26.90 \\
\hline 1984 & 23.10 & 21.20 & 21.60 \\
\hline 1987 & 20.10 & 16.10 & 17.40 \\
\hline 1990 & 16.80 & 14.3 & 15.10 \\
\hline 1993 & 13.40 & 13.80 & 13.70 \\
\hline 1996 & 9.70 & 12.30 & 11.30 \\
\hline 1997 & 13.39 & 19.78 & 17.47 \\
\hline 1998 & 21.92 & 25.72 & 24.20 \\
\hline 1999 & 19.41 & 26.03 & 23.43 \\
\hline 2000 & 14.60 & 22.38 & 19.14 \\
\hline 2001 & 9.79 & 24.84 & 18.41 \\
\hline 2002 & 14.46 & 21.10 & 18.20 \\
\hline 2003 & 13.57 & 20.23 & 17.42 \\
\hline 2004 & 12.13 & 20.11 & 16.66 \\
\hline 2005 & 11.68 & 19.98 & 15.97 \\
\hline 2006 & 13.47 & 21.81 & 17.75 \\
\hline 2007 & 12.52 & 20.37 & 16.58 \\
\hline 2008 & 11.65 & 18.93 & 15.42 \\
\hline 2009 & 10.72 & 17.35 & 14.15 \\
\hline 2010 & 9.87 & 16.56 & 13.33 \\
\hline Sep 2011 & 9.09 & 15.59 & 12.36 \\
\hline Sep 2012 & 8.60 & 14.70 & 11.66 \\
\hline Sep 2013 & 8.52 & 14.42 & 11.47 \\
\hline Sep 2014 & 8.16 & 13.76 & 10.96 \\
\hline Sep 2015 & 8.22 & 14.09 & 11.13 \\
\hline Sep 2016 & 7.73 & 13.96 & 10.70 \\
\hline Sep 2017 & 7.26 & 13.47 & 10.12 \\
\hline
\end{tabular}


However, around $10 \%$ of the entire population of Indonesia still lives under the poverty line in 2017 (Table 1.2). Poverty means that the individual has no financial security, whereas financial security comes from good financial decisions. According to Hussain and Sajjad in 2016 [6], financial literacy can be the solution for a country to escape from poverty. Financial literacy is a set of someone's awareness, knowledge, skill, attitude, and behavior to make proper financial decisions and reach his or her financial well-being [7]. Financial literacy covers both financial knowledge and the application in real life [8].

Muliaman, the Deputy Governor of Bank Indonesia, in 2008, said that only around 58\% of Indonesian people who lives in the urban area are financially knowledgeable. Then in 2016, OJK held a survey to assess Indonesia's financial literacy level. The result showed that Indonesia's financial literacy level was $29.66 \%$ in 2016, increased by $7.82 \%$ from 2013 (Figure 1).

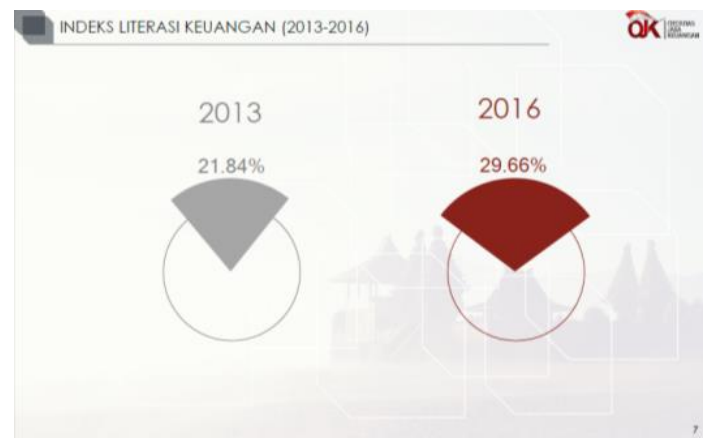

Figure 1. Financial Literacy Index of Indonesia 2013 and 2016 (Source: OJK, 2016)

The incremental was inversely proportional to the poverty rate in $2003-2006$. The rate was decreased from $11.47 \%$ in 2013 to $10.70 \%$ in 2016 (Table 1.2). Therefore, is there any relationship between financial literacy and poverty rate or wealth accumulation? There are several studies regarding the relationship between both things. A study by Van Rooij et al. found that financial literacy is positively affecting an individual's wealth accumulation [9] while another study by [10] found that financial knowledge is positively related with the experience with financial products and services.

Studies of the relationship between financial literacy and wealth accumulation in the family area seem rare in Indonesia. From the result of a pilot testing, we hoped to find the significant relationship between financial literacy and wealth of families in Bandung. It is expected that the results of the study will be beneficial regarding theory and practice for individuals, families, and government of Indonesia, or even other parties.

\section{LITERATURE REVIEW}

\section{A. Financial Literacy}

Financial literacy does not only cover knowledge but also applies in real life. An individual has to be able and confident to apply his or her financial knowledge in making financial decisions [6].

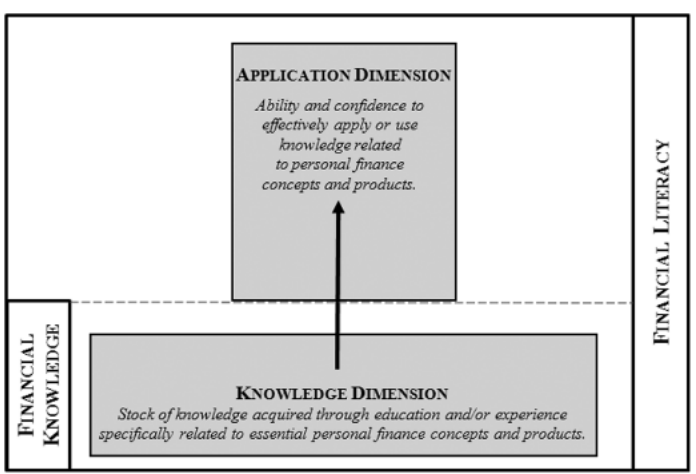

Figure 2. The concept of financial literacy Source: Huston, 2010 [8]

Financial literacy also has three competency categories that individuals need to have, which are financial knowledge, behavior, and attitudes.

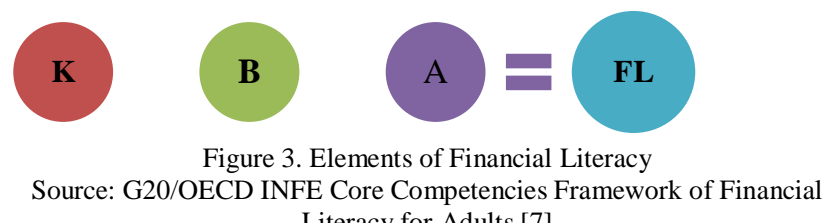
Literacy for Adults [7]

Nowadays, financial knowledge can be accessed through Medias. Financial skills and behavior category relate to how the persons act to achieve financial well-being. The last category, financial confidence, motivation, and attitudes, captures the internal or psychological mechanisms that may affect decisions, behaviors, and well-being of the individual.

\section{B. Wealth}

OECD in 2013 identified household wealth or sometimes called net worth, as a household's assets' value less the value of all its liabilities at a certain time and usually spread unequally. Wealth is higher on average than income because it is accumulated over time and harder to be measured than income. To identify a household's wealth, a researcher must identify these three components, which are non-financial assets, financial assets, and liabilities [11].

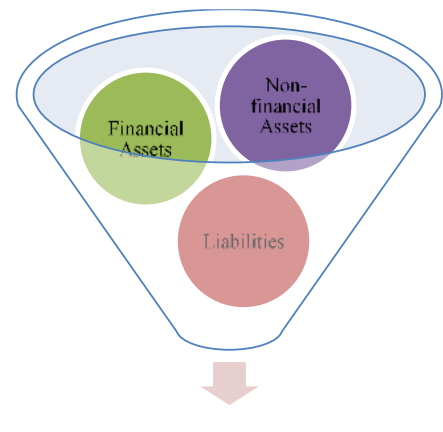

WEALTH

Figure 4. Components of Wealth

Source: OECD 2013 Framework for Statistics on the Distribution of Household Income, Consumption, and Wealth [11]

\section{Methodology}

The research is started by identifying the problem than defining the research questions, scope, and limitation. The next step is searching for relevant literature to support the research. After reviewing the literature, the researcher 
collects the data from secondary resources to support the research, such as journals, textbooks, research publications that relevant to the research topic.

For the primary data, the researcher distributed questionnaires and targeting West Java families as the population of the research. The samples of this research are families who live in Bandung. The data used in this pilot study was gathered in middle February 2018 through questionnaires about respondent's financial literacy index and wealth. The researcher used the OECD INFE Financial Literacy Questionnaire Toolkit as a reference for financial literacy measurement and PSID Wealth Accumulation Questionnaire as a reference to measure wealth accumulation in households. Some questions were adjusted to consider the current situation of households in Bandung city and to reach the objectives of this research. Here is the conceptual framework used to adjust the questionnaire [12]:

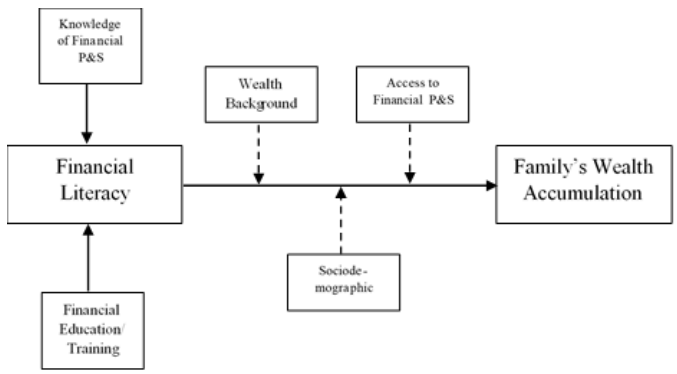

Figure 5. Research Framework

Source: Danella, Rahadi, and Helmi, 2017 [12]

According to Connelly in 2008, pilot test sample size should be $10 \%$ of sample projected for the more extensive study, which is ten respondents of 100 respondents [13]. This study used descriptive statistics to interpret the results, considering the amount of data used. This research also collects data from secondary resources to support the research.

\section{RESEARCH RESUlTS}

\section{A. Demographics Information}

The questionnaire was divided into six parts based on the research framework. This pilot study used data gathered from 10 respondents who live in Bandung city and one respondent who lives in Bandung district. Here are the demographic characteristics of the respondents in this study:

\begin{tabular}{cccc}
\multicolumn{5}{c}{ TABLE 3 RESPONDENTS' DEMOGRAPHIC CHARACTERISTICS } \\
Resp. & Gender & Age & $\begin{array}{c}\text { a million rupiah } \\
\text { Marital }\end{array}$ \\
\hline 1 & $\mathrm{~F}$ & The $40 \mathrm{~s}$ & $\mathrm{M}$ \\
2 & $\mathrm{M}$ & The $40 \mathrm{~s}$ & $\mathrm{M}$ \\
3 & $\mathrm{~F}$ & The $40 \mathrm{~s}$ & $\mathrm{~S}$ \\
4 & $\mathrm{~F}$ & The $20 \mathrm{~s}$ & $\mathrm{~S}$ \\
5 & $\mathrm{M}$ & The $20 \mathrm{~s}$ & $\mathrm{M}$ \\
6 & $\mathrm{~F}$ & The $70 \mathrm{~s}$ & $\mathrm{M}$ \\
7 & $\mathrm{M}$ & The $40 \mathrm{~s}$ & $\mathrm{~S}$ \\
8 & $\mathrm{M}$ & The $20 \mathrm{~s}$ & $\mathrm{M}$ \\
9 & $\mathrm{M}$ & The $40 \mathrm{~s}$ & $\mathrm{M}$ \\
10 & $\mathrm{~F}$ & The $40 \mathrm{~s}$ & $\mathrm{~S}$ \\
11 & $\mathrm{~F}$ & The $20 \mathrm{~s}$ & \\
Resp. & F. Status & Ethnic & Occupation \\
\hline 1 & $\mathrm{~W}$ & Sunda & Employee \\
2 & $\mathrm{H}$ & Sunda & Employee \\
3 & $\mathrm{~W}$ & Jawa & Home
\end{tabular}

\begin{tabular}{cccc}
4 & C & Sunda & Student \\
5 & C & Batak & Student \\
6 & W & Batak & Home \\
7 & H & Jawa & Entrepreneur \\
8 & C & Sunda & Looking \\
9 & H & Batak & Employee \\
10 & W & Sunda & Sick \\
11 & C & Sunda & Student \\
\hline
\end{tabular}

\begin{tabular}{ccc} 
Resp. & Region & Education \\
\hline 1 & Tegal Lega & HS \\
2 & Tegal Lega & HS \\
3 & Kordon & D \\
4 & Cibeunying & HS \\
5 & District & HS \\
6 & Karees & VS \\
7 & Arcamanik & M \\
8 & Tegal Lega & B \\
9 & Kordon & M \\
10 & Arcamanik & B \\
11 & Tegal Lega & HS \\
\hline
\end{tabular}

\begin{tabular}{ccc} 
Resp. & F. Income* & F. Expense* \\
\hline 1 & $<5$ & $<5$ \\
2 & $<5$ & $<5$ \\
3 & $10-<20$ & $10-<20$ \\
4 & $<5$ & $5-<10$ \\
5 & $<5$ & $<5$ \\
6 & $5-<10$ & $5-<10$ \\
7 & $5-<10$ & $5-<10$ \\
8 & $5-<10$ & $<5$ \\
9 & $20-<50$ & $10-<20$ \\
10 & $10-<20$ & $10-<20$ \\
11 & $<5$ & $<5$ \\
\hline \multicolumn{2}{r}{ Source: Author's Analysis }
\end{tabular}

\section{B. Financial Knowledge}

Financial knowledge is the principal financial concepts of a financially literate person [14]. Financial knowledge of respondents was measured with seven multiple choice questions regarding time value of money, interest paid on loan, interest and principle, compound interest, risk and return, inflation, and diversification. Respondents with at least 52.5\% right (compound interest question counted as right if interest and principal question are also right) included as respondents with high financial knowledge.

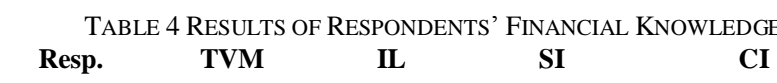

\begin{tabular}{lllll}
\hline 1 & 0 & 1 & 0 & 0 \\
2 & 1 & 1 & 0 & 0 \\
3 & 0 & 0 & 0 & 0 \\
4 & 0 & 1 & 0 & 0 \\
5 & 1 & 1 & 1 & 0 \\
6 & 1 & 1 & 1 & 0 \\
7 & 1 & 0 & 1 & 0 \\
8 & 1 & 1 & 1 & 0 \\
9 & 1 & 1 & 1 & 0 \\
10 & 0 & 0 & 0 & 0 \\
11 & 0 & 1 & 0 & \\
\hline
\end{tabular}




\begin{tabular}{|c|c|c|c|c|}
\hline & $55 \%$ & $73 \%$ & $45 \%$ & $9 \%$ \\
\hline Resp. & $\mathbf{R R}$ & I & D & Score \\
\hline 1 & 1 & 1 & 0 & $42.86 \%$ \\
\hline 2 & 1 & 1 & 0 & $57.14 \%$ \\
\hline 3 & 1 & 1 & 0 & $28.57 \%$ \\
\hline 4 & 1 & 1 & 0 & $42.86 \%$ \\
\hline 5 & 1 & 1 & 1 & $85.71 \%$ \\
\hline 6 & 1 & 1 & 0 & $71.43 \%$ \\
\hline 7 & 1 & 0 & 1 & $57.14 \%$ \\
\hline 8 & 1 & 1 & 1 & $85.71 \%$ \\
\hline 9 & 1 & 1 & 1 & $100.00 \%$ \\
\hline 10 & 0 & 1 & 1 & $28.57 \%$ \\
\hline \multirow[t]{3}{*}{11} & 1 & 1 & 0 & $42.86 \%$ \\
\hline & $91 \%$ & $91 \%$ & $45 \%$ & $54.54 \%$ \\
\hline & & & $\begin{array}{r}\text { Mean } \\
\text { Median } \\
\text { Max } \\
\text { Min } \\
\end{array}$ & $\begin{array}{c}58.44 \% \\
57.14 \% \\
100.00 \% \\
28.57 \% \\
\end{array}$ \\
\hline
\end{tabular}

Based on the result above, only six respondents got $52.5 \%$ of all questions right. Those five respondents who have lower financial knowledge are wives and female students, and most of them have a job or depending on their family members. Moreover, if we look at three respondents who have the highest knowledge among all, men tend to have higher financial knowledge. This result is consistent with the finding of Barber and Odean in 2001, said that men are more confident in financial knowledge and skills [15]. Findings in America also showed that male college students perform better in financial knowledge than females [16].

In average, most respondents still have lower knowledge about interest and principle, diversification, and mostly compound interest. In the other hand, most respondents have enough knowledge in risk-return and inflation. There is only one respondent that answered all questions correctly, while the two respondents with the lowest financial knowledge level only answered two questions right.

\section{Financial Behaviour}

It is vital for researchers to measure financial behavior because it captures how an individual behaves toward their money and it will have a significant impact on his or her financial wellbeing.

There are nine questions to measure the behavior, which consist of "carefully considers purchases", "pay bills on time", "keeps close on personal financial affairs", "long term goals and achieving them", "responsible and household budget", "actively saving or investing", "financial product (after gathering some info, after shopping around and using independent info or advice)", "has not taken loans to make ends meet'. Questions of "carefully considers purchases", "pay bills on time", "keeps close on personal financial affairs", "long term goals and achieving them" are semantic questions with rating 1 to 6 , where the bigger number indicates more positive behavior.

Respondents who scored at least 4 mean that they have positive behaviors. For the question "responsible and household budget", respondents who take part in their families' daily financial decisions and their families has a budget, got score 1 .

While in question "actively savings", respondents will get score one if they were actively saving in any forms, except by building up their balance in their current account because savings must be done intentionally, not a default position [14].

In "financial product", the researcher wants to know how the respondents chose financial products, whether they buy it with no information, based on their knowledge, or considering information from other people. The first question asked how the respondents chose financial products based on their knowledge or initiative.

Those who compare several options from one or more companies got score 1, then, respondents that use other independent information in choosing financial products got another 1 point.

The last question, "has not taken loans to make ends meet", the researcher wants to know whether the respondents use credits or loans to cover their deficit. Respondents who do not use credits or loans got 1 point. In the end, all scores summed and those scored at least five included as respondents who have positive financial behaviors.

TABLE 5 RESUlts OF RESPONDENTS' FINANCIAL BEHAVIOR

Behavior Statements

\begin{tabular}{|c|c|c|c|c|c|}
\hline Resp. & $\mathbf{a}$ & d & $\mathbf{f}$ & $\mathbf{g}$ & $R \& B$ \\
\hline 1 & 1 & 1 & 1 & 1 & 1 \\
\hline 2 & 1 & 1 & 1 & 0 & 1 \\
\hline 3 & 1 & 1 & 1 & 1 & 1 \\
\hline 4 & 1 & 1 & 1 & 1 & 1 \\
\hline 5 & 1 & 0 & 1 & 1 & 0 \\
\hline 6 & 1 & 1 & 1 & 1 & 1 \\
\hline 7 & 1 & 1 & 1 & 1 & 1 \\
\hline 8 & 0 & 0 & 0 & 0 & 1 \\
\hline 9 & 1 & 0 & 1 & 0 & 1 \\
\hline 10 & 1 & 0 & 0 & 1 & 1 \\
\hline 11 & 1 & 1 & 1 & 1 & 1 \\
\hline & $91 \%$ & $64 \%$ & $82 \%$ & $73 \%$ & $91 \%$ \\
\hline
\end{tabular}




\begin{tabular}{|c|c|c|c|c|c|}
\hline \multirow[t]{2}{*}{ Resp. } & \multicolumn{4}{|c|}{ Financial Product Choice } & \multirow{2}{*}{ Total } \\
\hline & AS & GI & SA\&II & NB & \\
\hline 1 & 1 & 1 & 1 & 1 & 9 \\
\hline 2 & 1 & 1 & 1 & 1 & 8 \\
\hline 3 & 1 & 0 & 0 & 1 & 7 \\
\hline 4 & 1 & 1 & 1 & 1 & 9 \\
\hline 5 & 1 & 1 & 1 & 0 & 6 \\
\hline 6 & 1 & 1 & 0 & 1 & 8 \\
\hline 7 & 1 & 1 & 1 & 1 & 9 \\
\hline 8 & 1 & 1 & 1 & 0 & 4 \\
\hline 9 & 1 & 1 & 1 & 1 & 7 \\
\hline 10 & 1 & 1 & 1 & 1 & 7 \\
\hline \multirow[t]{6}{*}{11} & 1 & 1 & 1 & 1 & 9 \\
\hline & $100 \%$ & $91 \%$ & $91 \%$ & $82 \%$ & $91 \%$ \\
\hline & & & & Mean & 7 \\
\hline & & & & Median & 8 \\
\hline & & & & $\operatorname{Max}$ & 9 \\
\hline & & & & Min & 4 \\
\hline
\end{tabular}

From the table above, we can see that $91 \%$ of 11 respondents already have positive financial behavior. The only respondent who has negative financial behavior is a $20 \mathrm{~s}$ years old man who is looking for a job. The respondent also has high financial knowledge and confidence regarding his financial knowledge".

This finding is supported by another literature said that higher financial knowledge does not always lead to positive financial behavior [15]. Respondents who scored perfectly consist of a wife and two female students, who rated their financial knowledge "average", and a husband who rated himself "low".

A study regarding college students also reported that female students tend to have a written budget, plan their expenditures, keep their bills and receipts, and save regularly than males [16]. Furthermore, we can know that all respondents reported being actively savings their money because most of them save their money in different forms, and almost half of them were having trouble paying their bills punctually.

\section{Financial Attitudes}

The last category of financial literacy is financial attitudes. This category assessed respondents' attitudes towards money and their plans. There are three questions regarding attitudes of "satisfying to spend than save", "live for today", and "money is there to spend".

These questions are semantic questions with rate 1 to 6 , where more significant scores indicate more positive attitudes. Respondents with average score at least 4 included as respondents that have positive attitudes.

Only seven of eleven respondents have a positive financial attitude. Those who have negative financial attitudes are two wives and two female students who admitted that they already got a financial education.

\begin{tabular}{|c|c|c|c|c|}
\hline Resp. & STS & LFT & MTS & Avg. \\
\hline 1 & 6 & 1 & 4 & 3.67 \\
\hline 2 & 6 & 2 & 4 & 4.00 \\
\hline 3 & 6 & 6 & 6 & 6.00 \\
\hline 4 & 2 & 3 & 3 & 2.67 \\
\hline 5 & 6 & 4 & 5 & 5.00 \\
\hline 6 & 5 & 5 & 3 & 4.33 \\
\hline 7 & 6 & 6 & 4 & 5.33 \\
\hline 8 & 5 & 5 & 4 & 4.67 \\
\hline 9 & 6 & 6 & 1 & 4.33 \\
\hline 10 & 2 & 3 & 4 & 3.00 \\
\hline 11 & 3 & 1 & 3 & 2.33 \\
\hline \multirow[t]{2}{*}{+} & $73 \%$ & $55 \%$ & $64 \%$ & $64 \%$ \\
\hline & & & $\begin{array}{r}\text { Mean } \\
\text { Median } \\
\text { Max } \\
\text { Min } \\
\end{array}$ & $\begin{array}{l}4.12 \\
4.33 \\
6.00 \\
2.33 \\
\end{array}$ \\
\hline
\end{tabular}

Source: Author's Analysis

Two of them have high financial knowledge level, while the other two have lower knowledge. There is only one respondent, a wife in her 70s, who got a perfect score and she admitted that she did not get any financial education and have no personal income. However, she scored low in financial knowledge.

While the respondents who have the second and third most positive attitudes are a male student that got a financial education and a husband that did not get any financial education, both have high financial knowledge. Respondents with positive financial attitudes do not always correlate with high financial knowledge.

A finding by [17] also showed that financial knowledge is positively correlated with financial attitudes and behavior, but it has a low degree of impact.

Then, averagely, the result showed that most respondents have positive attitudes in saving their money rather than spending it. However, some of them are still considering today's financial condition only.

\section{E. Financial Literacy}

After assessing the financial knowledge, behaviors, and attitudes of each respondent, the researcher combined three of them. Respondents who got high score got 1 point per each category.

A financially literate person must cover all categories: financial knowledge, financial behavior, and financial attitudes. The result showed that only 5 of 11 respondents who have high financial literacy, which can cope with all three competency categories.

Literature also said that financial knowledge is not the 
only factor that affects financial literacy, but financial attitudes and behavior also influence overall score [16]. These respondents consist of three husbands in their 40s and one male student in his 20s, who have got a financial education and a wife in her 70s who did not get a financial education.

\begin{tabular}{ccccc}
\multicolumn{2}{c}{ TABLE } & OVERALL & RESULTS OF RESPONDENTS' FINANCIAL LITERACY \\
Resp. & FK & FB & FA & Score
\end{tabular}

\begin{tabular}{|c|c|c|c|c|}
\hline 1 & $42.86 \%$ & 9 & 3.67 & 1 \\
\hline 2 & $57.14 \%$ & 8 & 4 & 3 \\
\hline 3 & $28.57 \%$ & 7 & 6 & 2 \\
\hline 4 & $42.86 \%$ & 9 & 2.67 & 1 \\
\hline 5 & $85.71 \%$ & 6 & 5 & 3 \\
\hline 6 & $71.43 \%$ & 9 & 4.33 & 3 \\
\hline 7 & $57.14 \%$ & 9 & 5.33 & 3 \\
\hline 8 & $85.71 \%$ & 4 & 4.67 & 2 \\
\hline 9 & $100.00 \%$ & 7 & 4.33 & 3 \\
\hline 10 & $28.57 \%$ & 7 & 3 & 1 \\
\hline \multirow[t]{2}{*}{11} & $42.86 \%$ & 9 & 2.33 & 1 \\
\hline & $55 \%$ & $91 \%$ & $64 \%$ & $45 \%$ \\
\hline
\end{tabular}

Their education backgrounds vary from high school, vocational school, and master's degree. Four of them rate their financial knowledge as "average" while the other one did not know how to rate himself.

Respondents who have medium financial literacy level (scored 2) are two wives in their 40s, an unemployed male in his 20 s and a female student in her 20s. While the two respondents who have low financial literacy level (scored 1) are a female student and a wife with no personal income and they already got a financial education.

This result is supported by the finding of Fonseca, Mullen, Zamarro, and Zissimopolous in 2012 [18]. They found that women tend to have lower financial literacy level than men empirically. The respondents also rated their financial knowledge as "average" among adults in their surroundings. These respondents came from a different educational background, which is high school and bachelor degree.

The wealth accumulation measurement results are divided into three categories, which are financial assets, nonfinancial assets, and liabilities.

\section{F. Financial Assets}

For financial assets part, there are multiple response combined with multiple choice question to measure ownership in checking or savings (savings, current/checking account, government bonds, money market account, time deposits, SBI / certificate of Bank Indonesia) and shares (publicly held corporations, mutual funds, investment trusts), while, to know the pension fund ownership, the researcher used a contingency question.

The table below showed that $82 \%$ of respondents have checking/savings assets, which is the highest among all categories of financial assets. Furthermore, most respondents have saving accounts, which compares with OJK financial inclusion survey 2016 results. The result said that bank products and services have the most participants among all financial assets with $63.63 \%$.

TABLE 8 RESPONDENTS' FinANCIAL ASSETS

*in million rupiah

Checking/Savings

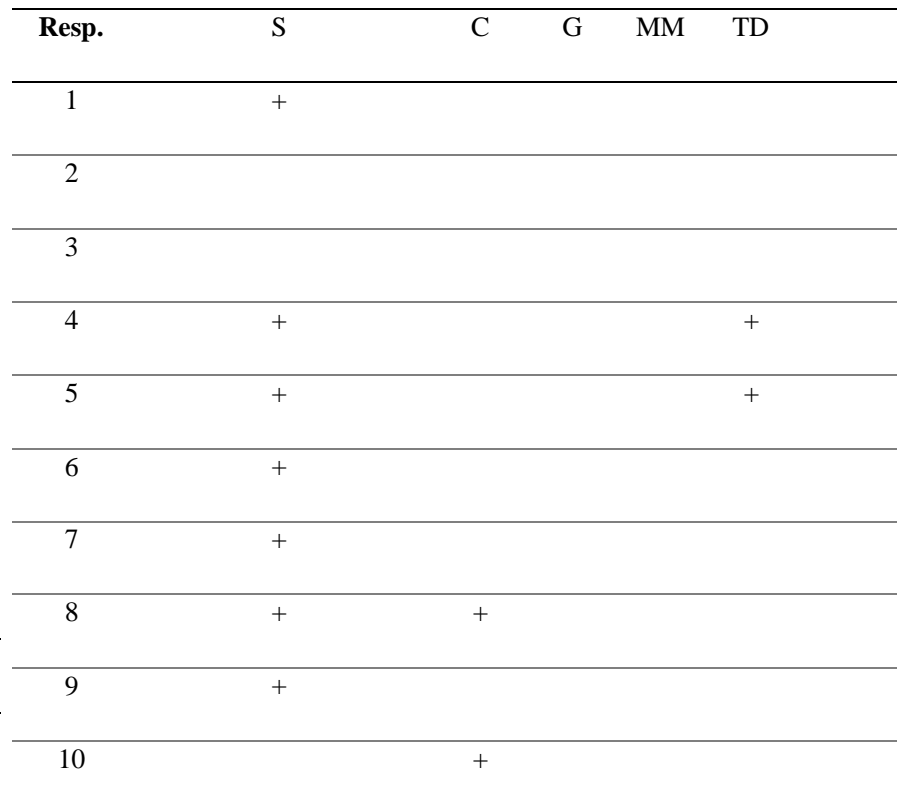

$\begin{array}{llllll}11 & + & & & & \\ & & & & & \\ \% & 73 & 18 & 0 & 0 & 18\end{array}$

\begin{tabular}{ccccccc}
\hline Resp. & \multicolumn{5}{c}{ Shares/Stocks } \\
\cline { 2 - 6 } & SBI & Net* $^{*}$ & PC & MF & IT & Net $^{*}$ \\
\hline 1 & & $1-<$ & & & + & $0-<$ \\
& 10 & & & & 1
\end{tabular}

2

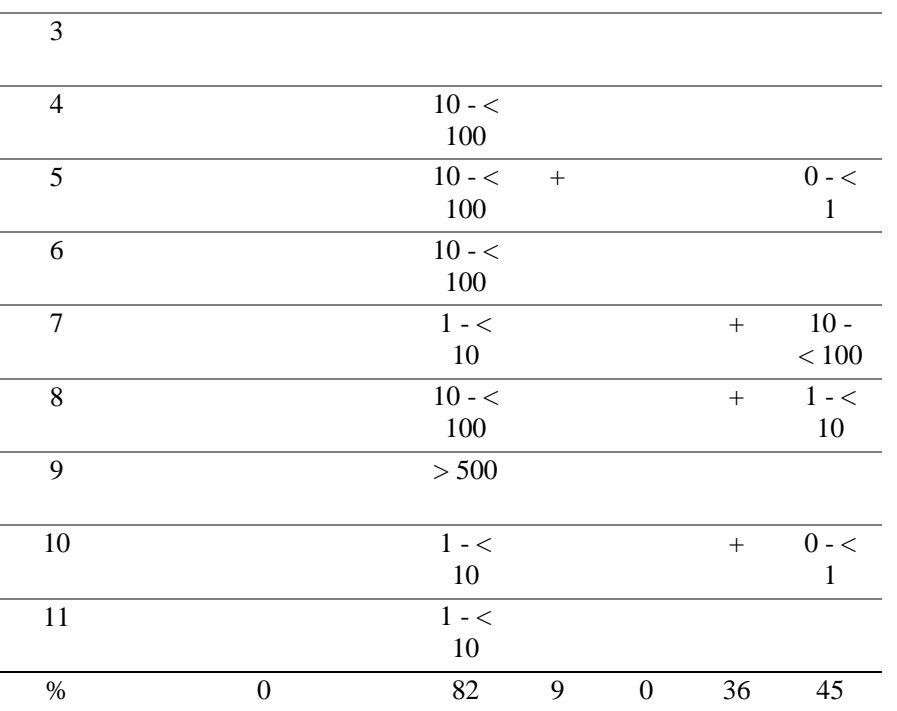




\begin{tabular}{ccc}
\hline Resp. & PENSION & Net* $^{*}$ \\
\hline 1 & + & $?$
\end{tabular}

$$
2
$$$$
3
$$$$
4
$$

\begin{tabular}{lcc}
5 & & \\
6 & + & $?$ \\
7 & + & $1-<$ \\
& & 10 \\
\hline 8 & + & 10 \\
& & 10
\end{tabular}

9

\begin{tabular}{ccc}
\hline 10 & + & $1-<$ \\
& & 10 \\
\hline 11 & + & $1-<$ \\
& & 10 \\
\hline
\end{tabular}

$\% \quad 55$

Source: Author's Analysis

The amount of the net worth varies: 4 respondents reported their families to have 1 to less than 10 million rupiahs, four respondents reported to have 10 to less than 100 million rupiahs, and one respondent reported to have more than 500 million rupiahs.

Those who do not have checking/savings account are a husband and a wife on their 40s whom both participated overall on their family financial decisions. However, if we look at their financial literacy level, the husband has high financial literacy level, while the wife has low financial literacy level because she does not have high financial knowledge.

Then, the respondent who has a most significant net worth in checking/savings account is a husband on his 40s, an employee has high financial literacy with a perfect score of financial knowledge and has the most prominent family income and expenditure per month among all. He also has high financial literacy knowledge.

The understandings of capital markets are still distributed unevenly among Indonesian people. Perhaps, it is the cause why the Indonesian stock market still has inadequate investors compare to the population.

The statement was supported by the result of the National Survey of Financial Literacy and Inclusion showing that only $1.25 \%$ of Indonesian people participated in the capital market, only $1.14 \%$ incremental from 2013. Furthermore, based on the results for shares/stocks, the respondents showed the lowest participation by $45 \%$.

There is only one respondent reported that his family has shares/stocks in a publicly held company(s); four respondents reported that their families have investment trusts; no one has a mutual funds account.

The respondent whose family have shares/stocks in a publicly held company(s) is a male student on his 20 s with family income and expense less than 5 million per month.
Respondents who have investment trusts are two wives on their 40s, a husband on his 40s too, and one single unemployed man on his 20s.

All of them participate in their daily families' financial decisions, and three of them participated overall. Only one of them has high financial literacy, while the rest have low financial knowledge, bad financial behavior, or negative financial attitudes. They also tend to feel wholly disagree with the statement "my money is there to be spent".

The amount of net worth of their shares/stocks also varies from 0 to less than 1 million rupiahs, 1 to less than 10 million rupiahs, and 10 to less than 100 million rupiahs. Three respondents reported their families 0 to less than 1 million rupiahs of a net worth of shares/stock, and only one respondent reported his family to have 0 to less than 1 million rupiahs of a net worth of shares/stock. The husband whose family has the most significant net worth has a high financial literacy with a perfect score on financial behavior, five to less than ten million rupiahs per month of family income and expense, and an entrepreneur.

More than half of all respondents already have pension funds. The respondents consist of a wife on her 70s, two wives on their 40s, a husband on his 40s, and one unemployed man on his 20s. Looking from their occupation, four of them have no personal income or no stability in income, and the other one is an employee

If we look at the averages, we can how the respondents participate in the financial market. Most respondents already have a savings account, and half of them already have pension funds. However, for other financial assets, such as checking/current account, time deposits, and investment trust, there is low participation of the respondents. The table also showed that nobody has government bonds, money market account, SBI, and mutual funds.

\section{G. Non-Financial Assets}

There are five kinds of non-financial assets measured in this study, which are business or farms, vehicles, homeownership, other property, and other assets.

TABLE 9 RESPONDENTS' NON-FINANCIAL ASSETS

\begin{tabular}{|c|c|c|c|}
\hline Resp. & BF* & $\mathbf{V}^{*}$ & $\begin{array}{l}*_{\text {in }} \text { million rupiah } \\
\mathbf{H}^{*}\end{array}$ \\
\hline 1 & $0-<10$ & $0-<100$ & $<200$ \\
\hline 2 & $<0$ & $<0$ & $200-<500$ \\
\hline 3 & & $200-<1.000$ & $500-<1.000$ \\
\hline 4 & & $0-<100$ & $200-<500$ \\
\hline 5 & & $100-<200$ & $<200$ \\
\hline 6 & & $100-<200$ & $200-<500$ \\
\hline 7 & $10-<200$ & $0-<100$ & $<200$ \\
\hline 8 & $10-<200$ & $100-<200$ & $200-<500$ \\
\hline 9 & $0-<10$ & $200-<1.000$ & $200-<500$ \\
\hline
\end{tabular}

10 


\begin{tabular}{cccc}
11 & $<0$ & $<0$ & $<200$ \\
\hline$\%$ & 45 & 91 & 91
\end{tabular}

\begin{tabular}{ccc} 
Resp. & OP* & OA* \\
\hline 1 & $<200$ & $10-<100$ \\
2 & & \\
3 & & $1-<10$ \\
4 & & $10-<100$ \\
5 & $200-<500$ & $1-<10$ \\
6 & $200-<500$ & $1-<10$ \\
7 & $200-<500$ & $10-<100$ \\
8 & $200-<500$ & $10-<100$ \\
9 & & \\
10 & & \\
\hline 11 & & Source: Author's Analysis \\
\hline$\%$ & &
\end{tabular}

The respondents' participation in non-financial assets is higher than in financial assets overall, mostly homeownership and vehicles. Then, for the net worth, there are two respondents reported that their families have negative net worth on both business/farm and vehicles.

These two respondents are a husband and a wife in their 40 s and admitted that they already got a financial education. They also participated in their families' daily financial decision-making process. Looking at their financial literacy, the husband tends to have high financial literacy while the wife is one of the respondents that have the lowest financial literacy score (mostly on financial knowledge). The financial attitude of the woman is only 1 point lower than the man.

Only six respondents reported that their families have business or farm. Those respondents consist of a wife in her $40 \mathrm{~s}$, three husbands on their $40 \mathrm{~s}$, a male student on his $20 \mathrm{~s}$, and a female student on her 20s. They admitted that they take part in their families' daily financial decisions, overall or together with other members. The net worth also varies from less than 0,0 to less than 10 million rupiahs, and 10 to less than 200 million rupiahs.

As already said before, respondents who reported their family to have a negative net worth of business or farm are a high financially literacy husband and a low financially literate wife in their 40s and admitted that they already got a financial education. While the respondents whose families that have the biggest business or farm net worth among all are a husband in his 40 s who works as an entrepreneur and a male student in his 20 s.

The entrepreneur has high financial literacy level (mostly financial behavior), while the student has low financial literacy level (mostly financial behavior). Both respondents are participated in their family's daily financial decisionmaking process, along with other family members. They also gave a similar score on the statement "I tend to live for today and let tomorrow happens", "It is more satisfying to spend money rather than saving it", "My money is there to be spent" and "I have too many debts".

There is only one respondent who reported that her family has no vehicles and homeownership. She is a wife in her 40s, lives in Arcamanik region and takes part in the daily financial decision-making process along with other members. However, she still has low financial literacy level, especially in the knowledge category. She also tends to spend her money and only considering today's condition.

Homeownership asset also got many participants with various values from less than 200 million rupiahs, 200 to less than 500 million rupiahs, and 500 million to less than 1 billion rupiahs. Respondent whose family has the most prominent home value is a wife in her 40s with low financial literacy who lives in Kordon region. She tends to have lower knowledge but has positive financial behavior and attitudes. She also admitted that she is the financial decision maker for her family alone and did not get any financial education. While respondents whose families have home value lower than 200 million rupiahs are a wife in her 40s who lives in Tegal Lega region, a husband in his 40s who lives in Arcamanik region, a male student in his 20 s who lives in Bandung district, and a female student in her 20s who lives in Tegal Lega region. The female respondents reported having a low financial literacy level (mostly financial attitudes), while the men have higher financial literacy level. However, the respondents seem to have positive financial behavior.

Then, in another property category, only five respondents whose families have this kind of non-financial assets. Four respondents' families reported to have 200 to less than 500 million rupiahs of other property's value, and one respondent's families reported to have other property with a value of less than 200 million rupiahs. The respondents consist of a wife in her 70s, two husbands in their 40s, and a male student. The wife and the husbands have high financial literacy level, while the student has lower financial literacy level (on financial behavior).

Last, there is $64 \%$ of respondents reported that their families have another asset with the amount from 1 to less than 10 million rupiahs, and 10 to less than 100 million rupiahs.

\section{H. Liabilities and Debt}

There are two kinds of debts measured in this study which are mortgage and other debts.

From the table above, we know that more than half of respondents have debts, whether it is a mortgage, other debts, or both. The mortgage has more significant participants than other debt with $82 \%$. The amount varies from less than 10 million rupiahs, 10 to less than 50 million rupiahs, and 100 less than 500 million rupiahs.

Those respondents whose families do not have a mortgage are a Bataknese male student in his 20s and a Bataknese wife in her 70s who both have high financial literacy. The student's family has a house with a value of 
fewer than 200 million rupiahs and the wife's family has a house with value 200 to less than 500 million rupiahs. While the respondents whose families have mortgage around 100 to less than 500 million rupiahs are a Javanese wife in her 40s, who has low financial literacy (on financial knowledge) and a Bataknese husband in his 40s who has financial literacy. Both respondents live in Kordon area but have different house value. The wife's family has a house with a value 500 to less than 1.000 million rupiahs, and the husband's family has a house with value 200 to less than 500 million rupiahs.

TABLE 10 RESPONDENTS’ LIABILITIES

\begin{tabular}{ccc} 
Resp. & M & OD \\
\hline 1 & $<10$ & $1-<10$ \\
2 & $<10$ & \\
3 & $100-<500$ & $1-<10$ \\
4 & $10-<50$ & $1-<10$ \\
5 & $10-<50$ & $10-<50$ \\
6 & $<10$ & \\
7 & $100-<500$ & \\
8 & $10-<50$ & $50-<100$ \\
9 & $<10$ & 52 \\
10 & Source: Author's Analysis \\
\hline 11 & & \\
\hline$\%$ & 82 & \\
\hline
\end{tabular}

\section{CONCLUSIONS AND RECOMMENDATIONS}

This paper has an objective to know how impactful financial literacy on family wealth accumulation in Bandung is. Several factors affect financial literacy level, which includes sociodemographic characteristics, financial knowledge, financial behavior, financial attitude, and financial training.

From the results above, we can assume that gender can affect an individual's financial literacy level, but not directly. We can see that women tend to have lower financial literacy level than men. Men tend to have a higher score on financial knowledge and financial attitudes, while the woman tends to have positive behavior. Individuals with jobs also tend to have higher financial literacy level. Perhaps independent individuals have a feeling of being responsible with the money they got. Like occupation, the husbands or the fathers of the family may have the feeling of being responsible for the family because they are the head of the family, so the husbands seem to have higher financial literacy score than wives and children. However, it seems that other sociodemographic characteristics, such as age, marital status, region, education, family income, and family expense have no enough impact in someone's financial literacy level as gender, occupation, and family status.

Wealth background seemed to have more impact on wealth accumulation rather than financial literacy, especially on homeownership or other property. However, the impact of wealth background seems low. Most respondents already have saving accounts; however, for other financial assets, Bandung people still have low participation. The higher the financial literacy level, the bigger the net worth. Same with shares/stocks, individual who has high financial literacy level tend to have a more significant amount of shares/stocks net worth. Unfortunately, most of the shares/stock owners in Bandung still have low financial literacy level. Then, participation in the pension fund of Bandung's families is quite high. However, the amount of the net worth seems low to fund their retirement period. Financial literacy has a low impact on participation in pension funds. Compared to financial literacy, Bandung people seem more interested in non-financial assets. Wealth background has a few impacts on the family's wealth, especially on homeownership or other property. For liabilities, the respondent with higher financial literacy level, are families who tend to have one kind of debt, mortgage or other debts.

\section{REFERENCES}

[1] Nidar, S. R., \& Bestari, S. (2012). Personal financial literacy among university students (case study at Padjadjaran University students, Bandung, Indonesia). World Journal of Social Sciences, 2(4), 162171.

[2] Hill, H. (2000). The Indonesian Economy. Cambridge University Press.

[3] Suryahadi, A., Hadiwidjaja, G., \& Sumarto, S. (2012). Economic growth and poverty reduction in Indonesia before and after the Asian financial crisis. Bulletin of Indonesian Economic Studies, 48(2), 209227.

[4] World Bank. (2017, September 19). Access mode: http://www.worldbank.org/en/country/indonesia/overview

[5] Badan Pusat Statistik. (2018, January 5). Jumlah Penduduk Miskin, Persentase Penduduk Miskin dan Garis Kemiskinan, 1970-2017. Access mode: https://www.bps.go.id/statictable/2014/01/30/1494/jumlah-pendudukmiskin--persentase-penduduk-miskin-dan-garis-kemiskinan--19702017.html

[6] Hussain, I., \& Sajjad, S. (2016). Significance of Financial Literacy and Its Implications: A Discussion. Journal of Business Strategies, $10(2), 141$.

[7] OECD INFE (2011) Measuring Financial Literacy: Core Questionnaire in Measuring Financial Literacy: Questionnaire and Guidance Notes for conducting an Internationally Comparable Survey of Financial literacy. Paris: OECD.

[8] Huston, S. J. (2010). Measuring financial literacy. Journal of Consumer Affairs, 44(2), 296-316.

[9] Van Rooij, M. C., Lusardi, A., \& Alessie, R. J. (2012). Financial literacy, retirement planning and household wealth. The Economic Journal, 122(560), 449-478.

[10] Hogarth, J. M., \& Hilgert, M. A. (2002). Financial knowledge, experience and learning preferences: Preliminary results from a new survey on financial literacy. Consumer Interest Annual, 48(1), 1-7.

[11] OECD (2013), OECD Framework for Statistics on the Distribution of Household Income, Consumption and Wealth, OECD Publishing. Access mode: http://dx.doi.org/10.1787/9789264194830-en

[12] Danella, J., Rahadi, R. A., \& Helmi, I. (2017). A Conceptual Study on the Impact of Financial Literacy Level to Household Wealth in Bandung. Journal of Humanities, Language, Culture and Business, 1(6), 82-93.

[13] Connelly, L. M. (2008). Pilot studies. Medsurg Nursing, 17(6), 411 413.

[14] Atkinson, A., \& Messy, F. A. (2011). Assessing financial literacy in 12 countries: an OECD/INFE international pilot exercise. Journal of Pension Economics \& Finance, 10(4), 657-665. 
[15] Barber, B. M., \& Odean, T. (2001). Boys will be boys: Gender, overconfidence, and common stock investment. The quarterly journal of economics, 116(1), 261-292.

[16] Chen, H., \& Volpe, R. P. (2002). Gender differences in personal financial literacy among college students. Financial services review, 11(3), 289.

[17] Mandell, L., \& Klein, L. S. (2009). The impact of financial literacy education on subsequent financial behavior.

[18] Hayhoe, C. R., Leach, L. J., Turner, P. R., Bruin, M. J., \& Lawrence, F. C. (2000). Differences in spending habits and credit use of college students. The Journal of Consumer Affairs, 34, 113-133

[19] Bhushan, P., \& Medury, Y. (2014). An Empirical Analysis Of Inter Linkages between Financial Attitudes, Financial Behaviour and Financial Knowledge of Salaried Individuals. Indian Journal of Commerce and Management Studies, 5(3), 58.

[20] Fonseca, R., Mullen, K. J., Zamarro, G., \& Zissimopoulos, J. (2012). What explains the gender gap in financial literacy? The role of household decision making. Journal of Consumer Affairs, 46(1), 90106

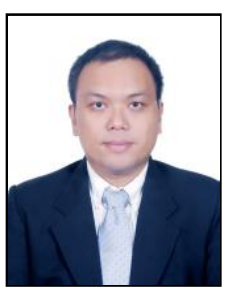

R. A, Rahadi has direct experience working for 15 (fifteen) years in real estate, property, architecture, design, investment management, financial consulting and research industry. Holds a bachelor degree in Architecture Engineering from Bandung Institute of Technology, hold two master degrees in Management from Swiss German University, Indonesia and in Business Administration from Fachhochschule Konstanz - Hochschule für Technik, Wirtschaft und Gestaltung, Germany, holds a Doctorate degree in Management Science from School of Business and Management, Bandung Institute of Technology.

Holds Qualified Wealth Planner (QWP @ ) certification from IAFP Global, International NLP Basic Practitioner Certificate from National Federation of Neuro-Linguistic Programming (NFNLP), and Registered Financial
Associate (RFA ® ) Certificate from International Association of Registered Financial Consultants.

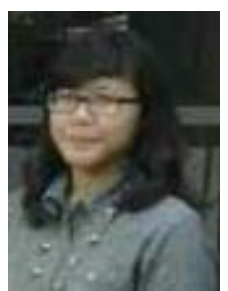

J. Danella got her bachelor's degree in Management from School of Business and Management, ITB. During her study, Jasmine conducted several projects and business cases. Currently, she is working in a consulting company as an associate consultant. In the past one year, Jasmine participated in several projects, such as feasibility study, survey, research, and organizational redesign for public companies.

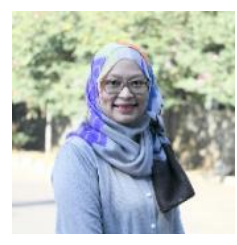

L. Okdinawati is a faculty member at the School of Business and Management, Institut Teknologi Bandung (SBM-ITB) and joined the sub interest groups of Operation and Performance Management. She graduated as Bachelor of Civil Engineering from Institut Teknologi Nasional, Indonesia and Master of Transportation from Institut Teknologi Bandung, Indonesia. Liane holds a Doctorate degree with Distinction (Cum Laude) in Science Management from School of Business and Management, Institut Teknologi Bandung, Indonesia.

She earned five international certifications for Affiliate - Chartered Institute of Logistics and Transport (CILT) in 2010, Certified Strategic Warehousing And Distribution Professional (CWDP) in 2015, Certified International Supply Chain Professional (CISCP) in 2015, SCM510 (Inventory Management \&; Physical Inventory) SAP ERP System in 2016 , and IATA Dangerous Goods Regulations - Initial Type A in 2016. 